\title{
External revascularisation for pseudochronic total occlusion of the dorsal pedis artery due to foot drop with severe diabetes mellitus
}

\author{
Nakabayashi Keisuke, Matsui Akihiro, Hiroshi Ando, Minoru Shimizu
}

Heart Center, Kasukabe Chuo General Hospital, Saitama, Japan

\section{Correspondence to} Dr Nakabayashi Keisuke, keisuke2018@gmail.com

Accepted 19 June 2017
CrossMark

\section{To cite: Keisuke $\mathrm{N}$}

Akihiro M, Ando H, et al. BMJ Case Rep Published Online First: [please include Day Month Year]. doi:10.1136/ bcr-2017-220633

\section{DESCRIPTION}

A 45-year-old woman with end-stage renal disease and severe diabetes mellitus (haemoglobin A1c (HbA1c) 9.5\%) suffered from critical limb ischaemia (CLI). Her right ankle brachial pressure index (ABPI) was 0.77; however, her left ABPI was immeasurable with flat waveform. Additionally, skin perfusion pressure was $34 \mathrm{~mm} \mathrm{Hg}$ on the left dorsal and $22 \mathrm{~mm} \mathrm{Hg}$ on the left planter. The angiography showed chronic total occlusion (CTO) of the dorsal pedis artery (DPA) (figure 1, left panel). We electively performed endovascular therapy. The soft wire smoothly passed the CTO of the DPA. We dilated the CTO with a $2.0 \mathrm{~mm}$ balloon several times; however, blood flow could not be restored. This discrepancy suggested an unusual CTO. Intravascular ultrasound showed an intact DPA. She also had foot drop due to diabetic neuropathy. Since the entry of CTO was at the dorsal ankle joint, this joint abnormality was considered the cause of the CTO. Manual dorsiflexion of the left ankle joint released the obstruction, 'pseudo CTO' (figure 1, right panel). Her left ABPI improved to 1.18 with dorsiflexion. We concluded that the foot drop caused her limb ischaemia.

'External revascularisation' is one of the CLI treatments. We used total contact cast therapy ${ }^{1}$ and negative pressure wound therapy to maintain dorsiflexion of her ankle angle and started non-weightbearing gait training simultaneously (figure 2). Her

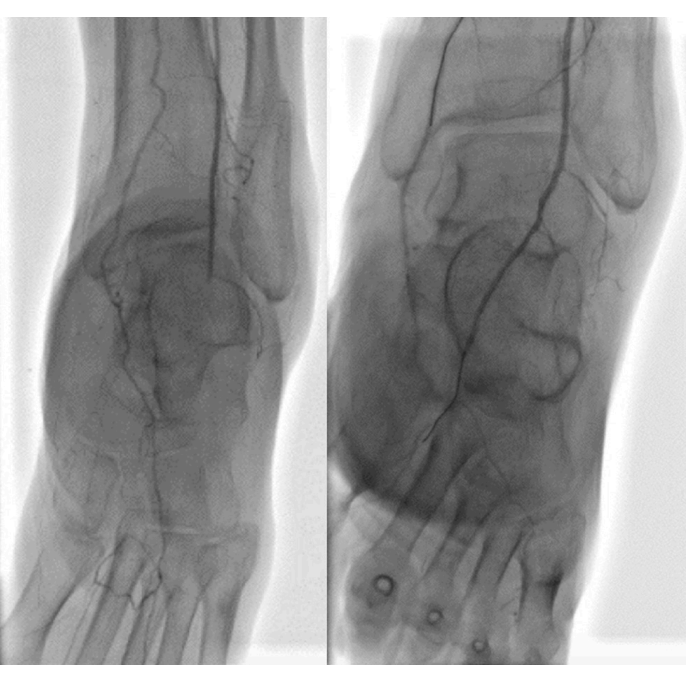

Figure 1 Left panel: the dorsal pedis artery was occluded abruptly like chronic total occlusion at the left ankle joint level. Right panel: manual dorsiflexion relieved the obstruction.

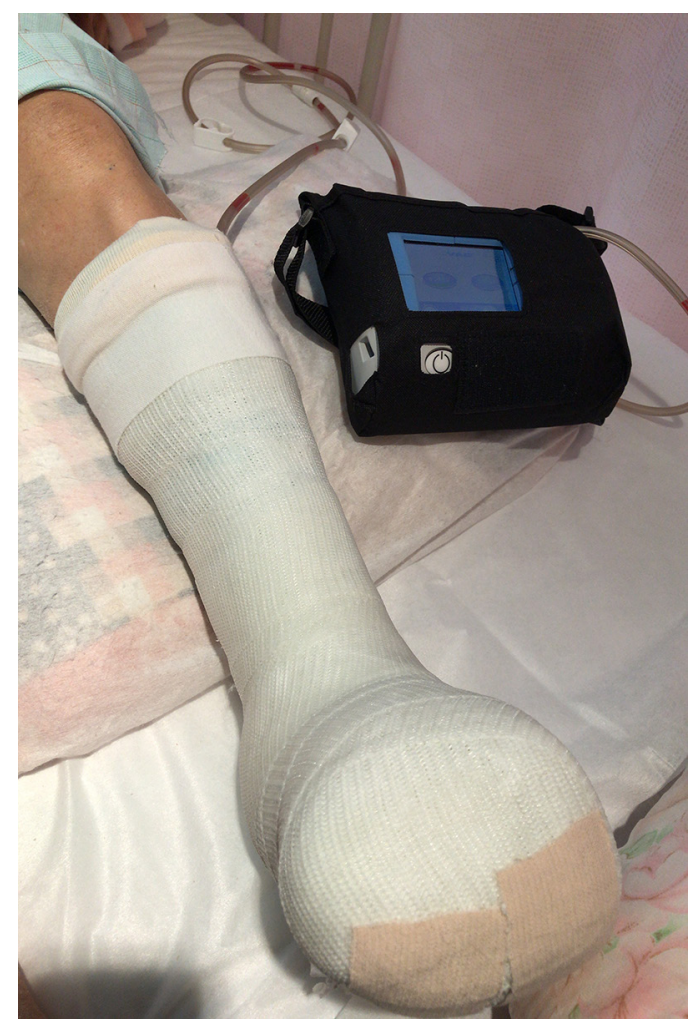

Figure 2 The combination of total contact cast therapy and negative pressure wound therapy. The former keeps the ankle right angle. The latter contributes to early wound healing.

wound was cured in 2 months. To the best of our knowledge, this is the first report describing the obstruction of the DPA due to foot drop. Foot

\section{Learning points}

- Foot drop, a concomitant disorder of diabetes mellitus, causes the occlusion of the dorsal pedis artery. Additionally, ankle dorsiflexion leads to external revascularisation, not internal intervention.

- The combination of total contact cast therapy and negative pressure wound therapy is reasonable for keeping dorsiflexion and non-weight-bearing, which contributes to a patient's cure and early rehabilitation.

- The strategy of limb salvage is wide ranging so that many professions must work together as a team. 
drop is a common disease whose most frequent cause is a peroneal neuropathy. However, diabetes mellitus is also one of the causes of this disease. ${ }^{2}$ We need to consider various aetiologies of vascular obstruction and the appropriate therapy for patients with foot drop.

Contributors NK wrote mainly this manuscript. NK, MA, HA and MS designed this concept. HA and MS supervised it.

Competing interests None declared.

Patient consent Obtained.
Provenance and peer review Not commissioned; externally peer reviewed.

(c) BMJ Publishing Group Ltd (unless otherwise stated in the text of the article) 2017. All rights reserved. No commercial use is permitted unless otherwise expressly granted.

\section{REFERENCES}

1 Armstrong DG, Lavery LA. Evidence-based options for off-loading diabetic wounds. Clin Pediatr Med Surg 1998; 15:95-104.

2 Stewart JD. Foot drop: where why and what to do ?. Pract Neurol 2008:8:158-69.

Copyright 2017 BMJ Publishing Group. All rights reserved. For permission to reuse any of this content visit http://group.bmj.com/group/rights-licensing/permissions.

BMJ Case Report Fellows may re-use this article for personal use and teaching without any further permission.

Become a Fellow of BMJ Case Reports today and you can:

- Submit as many cases as you like

- Enjoy fast sympathetic peer review and rapid publication of accepted articles

- Access all the published articles

- Re-use any of the published material for personal use and teaching without further permission

For information on Institutional Fellowships contact consortiasales@bmjgroup.com

Visit casereports.bmj.com for more articles like this and to become a Fellow 